\title{
Slovarsko gradivo Ftičarjevega romana Za nápršnjek vedríne ${ }^{1}$
}

\author{
Natalija Ulčnik \\ Univerza v Mariboru, Filozofska fakulteta, Koroška cesta 160, SI - 2000 Maribor, \\ natalija.ulcnik@uni-mb.si
}

SCN III/1 [2010], 125-156

\begin{abstract}
Za nápršnjek vedríne $(2004,2006)$ avtorja Jožeta Ftičarja predstavlja prvi slovenski narečni roman, $\mathrm{v}$ širšem smislu pa ga lahko razumemo tudi kot nadaljevanje in nadgradnjo stare prekmurske knjižne ustvarjalnosti. V prispevku je analizirano in ovrednoteno slovarsko gradivo, ki je izšlo kot dodatek k romanu. V njem je avtor zbral skoraj 3000 leksemov, za katere je predvideval, da jih sodobni (ne)prekmurski bralec ne bi mogel razumeti. Pomen slovarja se pokaže tudi v okviru prekmurskega narečnega slovaropisja, saj so vanj vključene številne enote, ki pred tem še niso bile evidentirane.
\end{abstract}

Za nápršnjek vedrine $(2004,2006)$ by Jože Ftičar represents the first Slovene novel written in dialect. In a broader sense it can be considered the continuation and upgrading of the old Prekmurje literary production. The present paper aims to analyze and evaluate the lexicographical material issued as a supplement to the novel. In it the author gathered almost 3,000 entries for items that he assumed the reader of standard Slovene would have difficulty understanding. The dictionary has also proven significant for Prekmurje dialect lexicography, since it includes entries that had not yet been registered.

Ključne besede: Jože Ftičar, Za nápršnjek vedrine, narečni roman, slovar, prekmursko narečje, prekmurski knjižni jezik

Key words: Jože Ftičar, Za nápršnjek vedrine, dialect novel, dictionary, Prekmurje dialect, Prekmurje literary language

${ }^{1}$ Prispevek je nastal v okviru raziskovalnega projekta J6-2238 z naslovom Slovenski jezik v stiku evropskega podonavskega in alpskega prostora, ki ga financira Agencija za raziskovalno dejavnost RS; odgovorni nosilec projekta je red. prof. dr. Marko Jesenšek. 


\section{Uvod}

Jože Ftičar, dialektolog, prevajalec, scenarist in prekmurski narečni pisatelj (Just 2006: 184), je roman Za nápršnjek vedríne, ki je v prvi vrsti namenjen Prekmurcem, objavil v dveh delih. ${ }^{2}$ Romaneskno besedilo, katerega značilnost je pisemska zgradba, je prvo, v celoti pisano v prekmurskem narečju oz. v njegovi dolinski različici, ${ }^{3}$ vendar bi lahko pri tovrstnih besedilih govorili tudi o nadaljevanju in nadgradnji stare prekmurske knjižne ustvarjalnosti. ${ }^{4}$ Zaradi predstavljenega obdobja (od tridesetih let 20. stoletja do konca druge svetovne vojne) je roman pomemben zgled postopnega jezikovnega približevanja obeh bregov reke Mure. Avtor je kot dodatek k romanu objavil tudi Slovar narečnih besed in besednih zvez dólinskega Prekmurja, v katerem je zbral skoraj tri tisoč geselskih (pod)iztočnic, za katere je predvideval, da jih sodobni (ne)prekmurski bralec ne bi mogel razumeti.

Ftičarjev roman Za nápršnjek vedríne so že ovrednotili literarni zgodovinarji (Čeh 2007a, 2007b) in slovstveni folkloristi (Stanonik 2008), v prihodnje pa je zaradi izvirnega in zanimivega narečnega gradiva pričakovano, da bo roman postal tudi vir dialektoloških raziskav. Njegov slovarski del, ki je izšel kot dodatek k romanu, si zasluži posebno obravnavo, saj je tudi neodvisno od romana pomembno avtorjevo strokovno delo.

\section{Slovarček kot dodatek (narečnim) leposlovnim besedilom}

Literarni avtorji (zlasti socialni realisti) so v svoja knjižnoslovenska besedila pogosto vnašali pokrajinsko pogovorne ali narečne besede oz. besedne zveze (t. i. regionalizme in dialektizme), ki so postale opazna stilna prvina literarnega besedila. ${ }^{5}$ Zavedali so se, da ti leksemi, ki pogosto opozarjajo na pokrajinske jezikovne posebnosti ali karakterizirajo literarne osebe (Čeh 2007a: 666), ne bodo širše razumljivi, zato so se odločili za njihovo pomensko pojasnjevanje. To so naredili s podčrtno opombo na isti strani, kar se zdi v odnosu do bralca najprimernejše, ali pa so razlago besed podali na koncu romana v obliki slo-

\footnotetext{
${ }^{2}$ Prvi je izšel leta 2004, drugi leta 2006. Roman je od leta 1980 v nadaljevanjih izhajal v zborniku Stopinje.

${ }^{3}$ V Prekmurju ločujemo tri podnarečja, in sicer goričko (severno), ravensko (osrednje) in dolinsko (južno) podnarečje (prim. Greenberg 1993, Zorko 2005, Koletnik 2008).

${ }^{4}$ Marija Stanonik (2007: 382-383) se sprašuje o upravičenosti uvrščanja tega romana k slovenski narečni književnosti, saj se dogajanje v romanu razvija v obliki pisem, torej izključno na podlagi pisane besede, narečje pa predpostavlja govorjeno obliko jezika. Tudi Peter Weiss (2000: 34) opozarja, da je »narečje v literarni rabi zapisano le približno in rado prehaja $\mathrm{v}$ nadnarečje $\ll$.

${ }^{5}$ Narečno besedišče daje leposlovju posebno žlahtno noto, ga obogati s pristnostjo in mu nikakor ni v breme (Stanonik 2007: 345).
} 
varčka. ${ }^{6}$ Nekatera sodobna prekmursko-porabska (nad)narečna leposlovna besedila pa so vzporedno prestavljena v knjižno slovenščino in s tem neposredno nagovarjajo vseslovenskega bralca, npr. mladinski roman Ferija Lainščka Pojeb na dejdekovom biciklini-Deček na dedovem kolesu (2001) ter porabske pripovedi Karla Holca z naslovom Andovske zgodbe - Andovske prpovejsti (2003).

$\mathrm{V}$ prekmurskih leposlovnih besedilih zasledimo veliko seznamov besed oz. t. i. aneksnih slovarčkov (prim. Weiss 2009: 53). Med prvimi je nastala Razlaga narečnih in manj znanih izrazov v romanu Ferda Godine Bele tulpike, ki jo je v tretji izdaji (leta 1972) pripravil Jože Ftičar. V njej najdemo 46 iztočnic, ${ }^{7}$ razvrščenih po zaporedju strani od začetka do konca romana. Zgradba aneksnega slovarčka je nazorna in za uporabnika preprosta: številki strani, s katere je beseda izpisana, sledi naglašena iztočnica z morebitno glasoslovno različico, v oklepaju je dodano ponazarjalno gradivo (smiselno okrajšan izpis iz romana z ležeče zapisano iztočnično obliko), slovarski sestavek zaključuje pomenska razlaga, ki je lahko knjižna ustreznica ali opisna razlaga, npr.:

str. 58: prišútati, tudi prišütati (prišutala je tiha jesen) - tiho priti, pritihotapiti se (Godina 1972: 275).

Pri treh iztočnicah je naveden tudi etimološki podatek (plebánuš iz lat. plebanus, batrìven iz madž. bátor, hasnovàti tudi hasnìvati iz madž. hasznát), pri eni najdemo oznako ironično (pŕdaš 'motorno kolo') in pri eni krajevno področje rabe: ógrad tudi òugrad (Bistrica v Prekmurju).

$\mathrm{V}$ romanih priznanega in večkrat nagrajenega vsestranskega ustvarjalca Ferija Lainščka, ki tematsko dosledno posega v prekmursko okolje, so uporabljene narečne besede pomensko pojasnjene v Slovarčkih manj znanih izrazov: v romanu Namesto koga roža cveti (2002) najdemo 37 dvodelnih gesel, ki jih je pripravil Franci Just, roman v treh novelah Ločil bom peno od valov (2003) vsebuje 35 takih gesel, njegovo vsebinsko nadaljevanje, roman Muriša (2006), pa 64 gesel.

Francek Mukič v Črnošolcu $(2007)^{8}$ podaja 130 gesel, zbranih pod naslovom Slovarček porabskih izrazov (str. 249-253). Vključuje eno- in večbesedne iztočnice (npr. mali žípan občinski sluga; pírožába netopir; ščàp za gra fižolovka), ob občnih imenih pa navaja tudi lastna imena, npr. Slavsko Jugoslavija; Vaugri, Vógrin Madžari, Madžar.

\footnotetext{
${ }^{6}$ Podobno je tudi v zbirki prekmurskih folklornih pripovedi z naslovom Brezglavjeki, Zgodbe s Prekmurja (razlaga besed pod vsako pripovedjo in Slovarček narečnih besed, str. 315-320; 372 gesel).

${ }^{7} \mathrm{~V}$ naslednjih izdajah je iztočnic nekoliko več, npr. v izdaji iz leta 1980 jih je 51.

${ }^{8}$ Mukič je besedilo sprva napisal v knjižni slovenščini, nato pa ga je prevedel v porabščino (Garaboncijaš; 2005) oz., kot ugotavlja Jože Ftičar, v »nadnarečni porabskoslovenski knjižni jezik« (Ftičar 2006: 164).
} 
Primer prvega v celoti (nad)narečnega prekmurskega literarnega dela je roman Jožeta Ftičarja Za nápršnjek vedríne, ${ }^{9}$ ki vsebuje slovarček z naslovom Slovar narečnih besed in besednih zvez dólinskega Prekmurja (I. del: str. 171-212, 1844 gesel; II del: str. 189-203, 858 gesel). Če bi ob iztočnicah upoštevali še podiztočnice, bi število doseglo tri tisoč leksemov.

Namen teh zbirk prekmurskega besedja je prekmurščino približati mlajši prekmurski generaciji, ki pogosto več ne razume besedja stare (knjižne) prekmurščine, ${ }^{10}$ ali pa neprekmurskemu bralcu, vendar poznavalcu prekmurščine. ${ }^{11}$ Bralec, ki prekmurščine ne razume, bi za razumevanje te besedne umetnine in spoznavanje njene literarne estetike potreboval vzporedni znotrajjezikovni prevod v knjižno slovenščino, pri tem pa bi se gotovo izgubila jezikovna arhaičnost in čustvena neposrednost. ${ }^{12}$

\section{Slovarsko gradivo Ftičarjevega romana}

Jože Ftičar je v prekmurskih dolinskih vaseh že med študijem zbiral narečno gradivo za Slovenski lingvistični atlas, kasneje tudi za Atlas slovanskih narečij. ${ }^{13}$ Napisal je slovarček za roman Bele tulpike Ferda Godine in sodeloval pri pripravi Slovarja slovenskega knjižnega jezika, kjer je bil (skupaj z Vilkom Novakom) svetovalec za prekmursko narečno skupino. Pri tem delu si je pridobil določene slovaropisne izkušnje, zato je pričakovanje, da je slovarski del v njegovem romanu premišljeno zasnovano strokovno delo, ki v marsičem odstopa od večinoma ljubiteljskih prekmurskih slovarjev in slovarčkov, upravičeno. ${ }^{14}$

${ }^{9} \mathrm{~V}$ knjižni slovenščini so le uvodni sinopsisi posameznih poglavij, a tudi v njih pogosto zasledimo narečne besede, npr.: »S. Sholastika v zaupnem pismu odvrača svaka od 'pintešije', kvarne za njegovo deco, in še spričo cemeštrije: ne moreš služiti dvema gospodoma« (Ftičar 2004: 54).

${ }^{10}$ To se potrjuje tudi pri delu s prekmurskimi študenti.

${ }^{11}$ Marija Stanonik kot raziskovalka iz osrednjeslovenskega območja priznava, da je bila zanjo recepcija prekmurskih literarnih besedil otežena, vendar dodaja, da se premagovanje jezikovnih ovir bogato poplača, saj je »seznanjanje in prodiranje v njune besedotvorne zakonitosti in slovnične lastnosti že samo na sebi svojevrsten estetski užitek« (Stanonik 2007: 382).

12 Tudi prestava prekmurskega mladinskega romana Pojeb na dejdekovom biciklini avtorja Ferija Lainščka v slovenski knjižni jezik (Deček na dedovem kolesu) je, kot ugotavlja Zinka Zorko (2005: 65), »mestoma papirnata, brez čustvenega naboja«.

${ }^{13}$ Prim. Fonološki opisi srpskohrvatskih/hrvatskosrpskih, slovenačkih i makedonskih govora obuhvaćenih opšteslovenskim lingvističkim atlasom. Glavni redaktor Pavle Ivić. Sarajevo: Akademija nauka i umjetnosti Bosne i Hercegovine, 1981, 11 (dostopno 29. 4. 2010 na: http://ola.zrc-sazu.si/OLA-VSE/FO_1981_000--026_UVOD.pdf).

${ }^{14}$ Ftičar je kot kompetenten presojevalec slovarskega dela ovrednotil tudi Mukičev Porabsko-knjižnoslovensko-madžarski slovar iz leta 2005. Opozoril je zlasti na pomanjkljivo (celo moteče) kvalifikatorsko označevanje zbranega gradiva in razjasnil nekatere 
Slovarček v romanu Jožeta Ftičarja je posebnost v slovenski slovaropisni praksi, saj bi ga po tipologiji lahko uvrstili med prave avtorske slovarje: avtor slovarja je hkrati tudi avtor izpisovanega besedila.

\subsection{Zgradba slovarskega sestavka}

Slovar narečnih besed in besednih zvez dólinskega Prekmurja je nastal na podlagi izhodiščno pisnega in ne govorjenega jezika ter posledično predvideva drugačnega uporabnika - bralca romana, zato je avtor temu prilagodil tudi slovarsko zasnovo. Iztočnice v svojem besedilnem okolju se pojavljajo v temeljnem delu romana, le-ta pa predstavlja izhodišče in povod za brskanje po slovarskem delu. Ftičar se je zavedal, da morajo biti informacije v slovarskem sestavku take, da bodo bralcu olajšale razumevanje izhodiščnega besedila, tj. romana, in mu na pričakovanem mestu ponujale čim več koristnih ter zanimivih jezikovnih podatkov. Tako se npr. snihìnje mlèjko pojavlja kot večbesedna iztočnica, ki je natančno pomensko pojasnjena in označena s kvalifikatorjem etnol. (= etnološko), medtem ko se v Novakovem slovarju beltinskega govora pojavi kot ponazarjalno gradivo brez pomenske pojasnitve, in sicer pod pridevniško iztočnico v osnovni slovarski obliki.

\begin{tabular}{|l|l|}
\hline Novak 1996: 136 & Ftičar 2004: 199 \\
\hline $\begin{array}{l}\text { snihìnji -a -e nevestin; snahin; véinec, } \\
\sim \text { m mléiko }\end{array}$ & $\begin{array}{l}\text { snihìnje mlèjko -a s (etnol.) mleko od } \\
\text { snehe - vino v čutari pozvačina }\end{array}$ \\
\hline
\end{tabular}

Tabela 1: Primerjalni prikaz izbranega slovarskega sestavka

Slovarski sestavek Ftičarjevega slovarčka vsebuje krepko zapisano in onaglašeno eno- ali večbesedno iztočnico, slovnične podatke, podatek o izvoru prevzetih besed (kajk. hrv., madž., iz nem., iz lat.), pomensko razlago (knjižnoslovensko ustreznico ali opisno razlago) ter v romanu izpričane stalne besedne zveze. Poudariti je potrebno zlasti v slovarju izpostavljene frazeološke zveze, ki so lahko: (1) navedene kot ponazarjalno gradivo v okviru običajnega slovarskega sestavka, npr. dvêri - dvér (mn.) s vrata, dveri; vrže žlìco za dvêri (etnol.) = umre; vjèsti (se) -vjen ugrizniti (se), vjèsti se za srcé potrpeti, požrtvovalno prenesti; zos -a m omaka; biti v zosi v škripcih, zadregi, godlji; ali (2) obravnavane samostojno, nemalokrat tudi v slovarski obliki, celo z nakazano variantnostjo, npr. làče zmèriti -zmèjrin / làče vöspràšiti -ášin pretepsti, našeškati (otroka); obláke krížati -an (etnol.) zvoniti ob hudi uri;

pomenske pomote (Ftičar 2006). Prim. tudi Greenbergovo oceno Mukičevega slovarja (2007). 
pravìce si dèlati oskrbeti si dokumente; vrrěti žlico v kòut, za dvêri (ljudski rek) umreti, izdihniti. ${ }^{15}$

Označevanje iztočnic z raznovrstnimi oznakami in pojasnili, ki dopolnjujejo pomensko razlago (npr. označevanje stilno in zvrstno zaznamovanih besed in besednih zvez: otr. govor, blaga kletvica, star., zaničljivo, ljubkovalno, ljudsko, etnol.), je v Ftičarjevem slovarju pogosto in izkazuje avtorjeve slovaropisne izkušnje ter prizadevanje za temeljito pomensko opredeljevanje. Kot leksikografsko posebnost je potrebno izpostaviti predvsem pragmatična pojasnila, saj gre $\mathrm{v}$ prekmurskem slovaropisju za redek primer njihove rabe.

\begin{tabular}{|c|c|c|c|c|}
\hline Vrste oznak/pojasnil & Oznaka & I. del & II. del & Skupaj \\
\hline \multirow{7}{*}{ etimološke } & hrv./iz hrv. & $2 / 0$ & $2 / 66$ & 70 \\
\hline & kajkav./kajk. hrv./hrv. kajk./iz kajk. hrv. & $1 / 4 / 0 / 1$ & $0 / 0 / 1 / 0$ & 7 \\
\hline & iz srh. & 0 & 1 & 1 \\
\hline & madž./iz madž. & $7 / 66$ & $31 / 6$ & 110 \\
\hline & iz madž. sintakse & 1 & 0 & 1 \\
\hline & nem./iz nem. & $1 / 14$ & $0 / 3$ & 18 \\
\hline & lat./iz lat. & $0 / 10$ & $0 / 0$ & 10 \\
\hline \multirow{3}{*}{ socialnozvrstne } & ljudsko, v ljudskem govoru/izražanju & 2 & 1 & 3 \\
\hline & v dijaškem žargonu & 0 & 2 & 2 \\
\hline & otroški žargon & 1 & 0 & 1 \\
\hline \multirow{2}{*}{ terminološke } & vojaško & 0 & 1 & 1 \\
\hline & etn., etnol. & 8 & 0 & 8 \\
\hline \multirow{5}{*}{ časovne } & star. & 155 & 53 & 208 \\
\hline & star. madž. & 1 & 0 & 1 \\
\hline & star. hrv. & 1 & 0 & 1 \\
\hline & nekdaj & 1 & 0 & 1 \\
\hline & v času SHS oziroma predvojne Jugoslavije & 0 & 1 & 1 \\
\hline pogostostne & redko & 2 & 0 & 2 \\
\hline \multirow{13}{*}{ čustvenostne } & karik. & 3 & 4 & 7 \\
\hline & rahlo/malo karik. & 1 & 1 & 2 \\
\hline & posmehljivo & 1 & 0 & 1 \\
\hline & pejor. & 8 & 1 & 9 \\
\hline & zaničljivo & 1 & 0 & 1 \\
\hline & ljubkovalno & 2 & 0 & 2 \\
\hline & otroški govor & 3 & 0 & 3 \\
\hline & otroški jezik & 1 & 0 & 1 \\
\hline & erot. & 1 & 0 & 1 \\
\hline & kletvica & 3 & 0 & 3 \\
\hline & omiljena kletvica & 1 & 3 & 4 \\
\hline & blaga kletvica & 1 & 0 & 1 \\
\hline & huda kletev v kmečkem okolju & 1 & 0 & 1 \\
\hline pomenske & $\mathrm{v}$ prenesenem pomenu & 2 & 2 & 4 \\
\hline
\end{tabular}

${ }^{15}$ Na različno vključevanje frazeološkega gradiva na nivoju slovarske makro- oz. mikrostrukture opozarja Vida Jesenšek (2009: 3). 


\begin{tabular}{|c|c|c|c|c|}
\hline \multirow{2}{*}{ frazeološke } & ljudski rek & 1 & 0 & 1 \\
\hline & rek & 0 & 2 & 2 \\
\hline \multirow{4}{*}{ zemljepisne/krajevne } & $\mathrm{v}$ panonskem prostoru & 0 & 1 & 1 \\
\hline & drugod v Prekmurju & 1 & 0 & 1 \\
\hline & drugod tudi & 1 & 0 & 1 \\
\hline & krajevno & 1 & 0 & 1 \\
\hline \multirow{3}{*}{ posebne } & tudi $^{16}$ & 7 & 19 & 26 \\
\hline & še v pomenu & 1 & 0 & 1 \\
\hline & in & 1 & 0 & 1 \\
\hline \multirow{7}{*}{ slovnične } & mn./nav. mn. & $30 / 1$ & $10 / 1$ & 42 \\
\hline & aor. & 1 & 0 & 1 \\
\hline & medm. & 4 & 0 & 4 \\
\hline & neskl. & 1 & 0 & 1 \\
\hline & 3. os./3. os. ed. & $10 / 0$ & $9 / 4$ & 23 \\
\hline & pret. & 4 & 4 & 8 \\
\hline & iter. & 1 & 0 & 1 \\
\hline \multirow{5}{*}{ pragmatične } & vljudnostni pozdrav & 1 & 0 & 1 \\
\hline & v gosposkem okolju & 1 & 0 & 1 \\
\hline & v kmečkem okolju & 1 & 0 & 1 \\
\hline & zunanji znak fantovstva & 1 & 0 & 1 \\
\hline & vzklik privoščljivosti & 0 & 1 & 1 \\
\hline
\end{tabular}

Tabela 2: Raba oznak in pojasnil v Ftičarjevem slovarju

V prvem delu se označevalnik ali pojasnilo pojavi pri 376 iztočnicah, V drugem delu pri 230 iztočnicah, kar skupaj predstavlja 22 odstotkov vseh iztočnic v slovarčku. Med etimološko pojasnjenimi besedami v 1. delu slovarja prevladujejo iz madžarščine prevzete besede, v 2. delu iz hrvaščine, to pa je pogojeno z družbeno-zgodovinskimi okoliščinami, ki jih prikazuje drugi del romana, in z zgodovinskim dejstvom, da je bil dolinski del Prekmurja zaradi priključenosti k zagrebški nadškofiji dolgo pod močnim kajkavskim vplivom (prim. Jesenšek 2005: 29-30). Če združimo podatke o izvoru besed prvega in drugega slovarskega dela, prevladujejo madžarske besede ${ }^{17}$ in besede, prevzete iz madžarščine, kar pa ne pomeni, da je v romanu madžarizmov več kot npr. besed nemškega izvora (slednje pogosto niso zajete v slovarček oz. niso označene). ${ }^{18}$

\footnotetext{
${ }^{16}$ Hierarhizacijski označevalnik tudi v prvem delu slovarja opozarja zlasti na drugotni pomen (npr. zdvojìti/zdvòjiti /.../ podvomiti; tudi: obupati), v drugem delu pa na glasoslovne ali besedotvorne različice, npr. gulùmbiš /.../ tudi: golùmbǐ̌; travnják /.../ tudi: travnjàča.

${ }^{17}$ V romanu (predvsem v pismih s. Sholastike, nune v budimpeštanskem samostanu) so pogosto pojasnjene tudi kot podčrtne opombe, npr. »(Orsolya zároda - ne ven, kak to po slovenski pravite)*: * Orsolya zár(o)da (madž.) - uršulinski samostan (Ftičar 2004: 141).

${ }^{18} \mathrm{Npr}$ šenkati, špic, špiu, štanga, šus, žmaj.
} 
Socialnozvrstni označevalniki so v narečnih slovarjih redki, pričakovano je le označevanje slengovskih in žargonskih besed (Weiss 2000: 34), v Ftičarjevem slovarčku pa se v treh primerih pojavi tudi nepričakovana oznaka ljudsko oz. v ljudskem govoru/izražanju, ki nakazuje splošnoprekmursko narečno rabo (npr. po štàjarski 'knjižno slovensko').

Tudi raba terminoloških označevalnikov v narečnih slovarjih ni pogosta, saj so besede $\mathrm{v}$ posamezna strokovna področja uvrščene $\mathrm{z}$ vidika stroke (prim. Weiss 2000: 36) in ne z vidika narečnega govorca. Ftičar je zgolj eno besedo označil kot vojaško (regrutèjrati 'rekrutirati, vpoklicati'), osem besed oz. besednih zvez pa je opredelil kot etnoloških (böšnják 'krošnjar', vrže žlìco za dvêri 'umre', màdaj 'hrust, silak', mak pàti 'phati mak: otroška igra', obláke krížati 'zvoniti ob hudi uri', pečnica 'peč za sušenje lanu in konoplje, tudi za žganje posode', ritovina/rijtovina 'za kritino pripravljen omlačen, prečesan in poravnan snop', snihinje mlèjko 'mleko od snehe (snahe, op. N. U.) - vino v čutari pozvačina'). ${ }^{19}$

Med časovnimi označevalniki je z 207 pojavitvami opazna krajšava star. (starinsko), kar lahko pojasnimo z dogajalnim časom romana.

Čustvenostni označevalniki ne izstopajo po pogostnosti, temveč po izkazani pestrosti, iz katere je razvidna avtorjeva jezikovna natančnost in tankočutnost, saj ločuje tudi posamezne odtenke čustvenostnih oznak (npr. karikirano, rahlo karikirano; kletvica, omiljena kletvica, huda kletev) in s tem presega obstoječe narečne slovarje.

$\mathrm{Na}$ izbor gradiva za slovarski del je torej vplivala tudi označenost leksema (lahko stilna, časovna, etimološka ...). Ob rabi označevalnikov pa se je avtor nemalokrat odločil tudi za pojasnjevanje leksikalne nenevtralnosti znotraj pomenskih razlag, npr.:

božnìja -e ž slaba stvar, hudobija, grda razvada;

divjàga -e ž divja, besna ženska;

nafřčkati -an napisati kaj na hitrico, načečkati, nakracati. ${ }^{20}$

Obravnavani slovar presega vse obstoječe aneksne slovarje, vendar nima znanstvenih ambicij in zato zahteva drugačna ocenjevalna merila; kljub temu bi lahko z vidika uporabnika opozorili na nekaj slovaropisnih pomanjkljivosti, ki so vezane zlasti na: (1) neustrezno gesljenje, npr. na Rovatsko (pod N) namesto Rovatsko (pod R), na tihinskon (pod N) namesto tihinsko (pod T); (2) manjkajoči podatek o spolu pri množinskih samostalnikih, npr. risáli -ov (mn.) namesto risáli -ov (mn.) m; škrepcé -ov mn. namesto škrepcé -ov mn. ž, (3) nedoslednosti pri navajanju etimoloških podatkov, npr. lüšt namesto lüšt (iz nem.), in (4) združevanje besed znotraj istega slovarskega sestavka (navajanje

${ }^{19}$ Prav za označevalnik etn. Weiss (2000: 36) navaja, da se ne pojavlja v nobenem narečnem slovarju.

${ }^{20}$ Pri sopomenski iztočnici naškrábati pa zasledimo knjižnoslovensko ustreznico napisati in označevalnik pejor. 
podiztočnic) tudi v primerih, ko bi bilo ustreznejše oblikovanje samostojnega slovarskega sestavka, npr. váraš 'mesto' - Váraš 'Turnišče'.

\subsection{Primerjava Ftičarjevega slovarskega gradiva z Novakovim Slovarjem beltinskega prekmurskega govora}

S primerjalno metodo sem skušala ugotoviti, v kolikšni meri je besedje Ftičarjevega slovarja prekrivno z besedjem narečnega Slovarja beltinskega prekmurskega govora, ki spada v prekmursko dolinsko podnarečje, iz katerega je izhajal tudi Ftičar.

\begin{tabular}{|l|l|l|}
\hline \multicolumn{2}{|l|}{$\begin{array}{l}\text { Število iztočnic v Ftičarjevem Slovarju } \\
\text { narečnih besed in besednih zvez dólinskega } \\
\text { Prekmurja }\end{array}$} & $\begin{array}{l}\text { S2004, 2006) } \\
\text { Stevilo iztočnic, prekrivnih z } \\
\text { Novakovim Slovarjem beltinskega } \\
\text { prekmurskega govora (1996) }\end{array}$ \\
\hline I. del & 1844 iztočnic & 1007 iztočnic $(54,6 \%)$ \\
\hline II. del & 858 iztočnic & 284 iztočnic $(33 \%)$ \\
\hline Skupaj & $\mathbf{2 7 0 2}$ iztočnici & $\mathbf{1 2 9 1}$ iztočnic $(\mathbf{4 7 , 7} \%)^{21}$ \\
\hline
\end{tabular}

Tabela 3: Prekrivnost iztočnic med Ftičarjevim in Novakovim slovarskim gradivom

Od 2702 iztočnic najdemo v Slovarju beltinskega prekmurskega govora 1291 iztočnic. V Ftičarjevem slovarju je torej glede na Novakov slovar nova dobra polovica besed. V prvem delu romana je obema slovarjema skupnih 1007 iztočnic $(54,6 \%)$, od tega se 145 iztočnic razlikuje le v podrobnostih, npr. v pravopisno različnem zapisu besede ali v zapisu glasov (na kráci : nakráci, ${ }^{22}$ bèjžati : béižati; pokópič : pokóupič; žüliti : žüiliti), v spremembi oblikoslovnih kategorij (gibice -íc (mn.) : gibica -e ž; frišek -ška -ško : friški-a-o; ščelínek - a m : ščelínka -e ž) ali v besedotvornem obrazilu (fundamèntuš : fundamènt; hüdòbnjek: hüdobnják). Od 858 iztočnic drugega dela romana jih v Slovarju beltinskega prekmurskega govora najdemo 284, kar predstavlja tretjino oz. 33 odstotkov. Od tega je 62 besed (21,8 \%) zapisanih v pisni, glasoslovni, oblikoslovni ali besedotvorni različici, npr. prejkzéti : préik zéti, cüknoti : cùknoti, gulùmbiš : golùmbiš; ràstveci (mn.) : ràstvec; šprìcar : šprìcer. Besede tudi pomensko niso vedno enako pojasnjene. Pri Ftičarju je ponekod razviden širši pomen oz. večpomenskost (̌̌pilaràj / špilaráj 'otroška igra, igranje, igrače' : špilaráj 'igrače'), opazen pa je tudi tip razlage z zapostavljenim prilastkom,

${ }^{21}$ Prekrivnost besedja s Slovarjem stare knjižne prekmurščine (2006) je precej nižja.

${ }^{22} \mathrm{Na}$ prvem mestu je izpis iz Ftičarevega slovarja, za dvopičjem sledi izpis iz Slovarja beltinskega prekmurskega govora. 
npr. čùrka -e ž cev (gumirana); gàter -tra m ograja (železna); slédnje mázanje -ega, -a s (star.) maziljenje (bolniško); šörc -a m predpasnik (moški).

Nekaterih besed v slovarju beltinskega govora ne zasledimo, ker so preveč specifične, povezane z vsebino, ki navadno ni dobro zastopana v splošnih slovarjih, npr. bolševizmuš, fiksavijon, internátuš, ižámen, raspištoliti, samozavejdanje. Pri Ftičarju pogosto najdemo abstraktne samostalnike z besedotvornima obraziloma -nje in -ost, ki v Novakovem slovarju niso navedeni, saj v narečju tudi ni prave potrebe po njihovi rabi: dobročinenje, dopadenje, jufkanje, klumanje, künštnost, nebogavnost, osvedočenjelosvidočenje, preporačanje, spovidavanje ...

Analiza je pokazala, da je Ftičarjevo slovarsko gradivo namenjeno tudi neprekmurskim bralcem, saj so pomensko pojasnjene tudi nekatere splošno znane prekmurske besede (gotovo znane vsem generacijam prekmurskih bralcev), npr. bèteg 'bolezen', guč 'govor, govorjenje, pomenek, kramljanje, govoranca'. Odvečne se zdijo razlage splošnoslovenskih besed, npr. híp ‘trenutek', prikázen 'prikazen, pojav', v kolikor ne opozarjajo na naglasne posebnosti, npr. dèdek 'ded, stari oče'.

V Ftičarjevem slovarju je veliko leksemov označenih kot starinskih, v slovarju beltinskega govora pa so neoznačeni, npr. dokončetek, dugovanje, grdostija, nakanenje, nevarnošča, preminočnost, zveličiteu, sakačica, spravišce, vadlüvati, vekivečnost, vmarjati, zamazek, ali pa imajo pojasnilo o rabi v cerkvenem jeziku, npr. odküpiteu (star.) : odküpiteu (v cerkvenem jeziku); vörovadlüvanje (star.) : vörevadlüvanje (v cerkvenem jeziku), zadostačinenje (star.) : zadostačineinje (v cerkvenem jeziku). Večino starinskih besed najdemo tudi v Slovarju stare knjižne prekmurščine (2006), kar pomeni, da gre v teh primerih za prekmursko besedje z dolgo knjižno tradicijo.

\section{Sklep}

Jože Ftičar je v romanu Za nápršnjek vedríne dokazal, da lahko prekmurščina, ki je slovarsko največkrat in najbolje obdelano slovensko narečje, uspešno opravlja vlogo literarnega jezika. Avtor je značilno, manj znano oz. posebno besedje tega romana izpisal in ga prikazal $\mathrm{v}$ dodatku $\mathrm{k}$ romanu, ki ga lahko štejemo za pomemben slovarski prispevek in dopolnilo obstoječim prekmurskim slovarjem, saj so vanj vključene številne enote, ki pred tem še niso bile evidentirane. ${ }^{23}$ Gre za poseben narečni slovar, ki je nastal na podlagi pisnega in ne izhodiščno govorjenega jezika, zato se iztočnice v svojem besedilnem

${ }^{23}$ Sistematično izpisovanje iz romana $\mathrm{z}$ namenom natančne slovarske predstavitve pa bi vsekakor lahko še dodatno obogatilo dosedanje prekmurske slovarje.

$\mathrm{Ob}$ tem se nam zastavi tudi vprašanje, koliko (nad)narečnega prekmurskega gradiva bo prišlo v novi slovar slovenskega jezika, o katerem so se strokovnjaki posvetovali oktobra 2008 (žal niso dorekli, ali bo zajeto tudi narečno gradivo in ali bo upoštevan govorjeni korpus). 
okolju pojavljajo v temeljnem delu romana, le-ta pa predstavlja izhodišče in povod za brskanje po slovarskem delu. Slovar v primerjavi s krajšimi narečnimi aneksnimi slovarčki izstopa po obsegu ter temeljitem navajanju pomembnih slovaropisnih oznak, ki prispevajo k vsestranskemu prikazu besedja.

Glede na Novakov slovar beltinskega govora, ki pripada isti prekmurski podnarečni skupini, je pri Ftičarju nova približno polovica besed, delno zaradi specifične vsebine, ki v splošnem narečnem slovarju ni zastopana, delno zaradi novih besedotvornih potreb pisnega (knjižnega) jezika. Analiza kaže, da Ftičarjev slovarček vsebuje tako sodobno narečno kot tudi arhaično knjižno prekmursko besedje, pri tem pa je slednje opremljeno z ustreznim časovnim označevalnikom.

Ftičarjevo slovarsko gradivo vsekakor presega potrebe prekmurskega naslovnika in je lahko dober pripomoček ne le bralcem romana kot primarno predvidenim uporabnikom, temveč vsem, ki si želijo pomensko razjasniti kakšno prekmursko besedo, bodisi v sodobnih prekmurskih besedilih bodisi v besedilih stare knjižne prekmurščine.

Jože FTIČAR, 2004: Za nápršnjek vedríne I. Murska Sobota.

- -, 2006: Za nápršnjek vedríne II. Murska Sobota.

Ferdo GODINA, 1972, 1980: Bele tulpike. Murska Sobota; Ljubljana.

Feri LAINŠČEK, 2002: Namesto koga roža cveti. 2. izdaja. Murska Sobota.

- -, 2003: Ločil bom peno od valov. Ljubljana.

- -, 2006: Muriša. Ljubljana.

Francek MUKIČ, 2007: Črnošolec. Porabska legenda. Murska Sobota.

Dušan REŠEK, 1995: Brezglavjeki. Zgodbe s Prekmurja. Glasovi, 9. knjiga. Ljubljana.

\section{LITERATURA}

Marija BAJZEK LUKÁCS, 2005: Prekmurščina v slovarjih. Prekmurska narečna slovstvena ustvarjalnost. Murska Sobota. 394-399.

Marija BAJZEK LUKAČ, 2009: Slovar Gornjega Senika A-L. Maribor. (Mednarodna knjižna zbirka Zora, 66).

Jožica ČEH, 2007a: Besedje kot prvina jezikovnega sloga ter metafora in simbol $\mathrm{s}$ teoretičnega in literarnozgodovinskega vidika. Besedoslovne spremembe slovenskega jezika skozi čas in prostor. Maribor: Slavistično društvo. (Zora 49.) 665-722. 
- -, 2007b: Prvi slovenski narečni roman. Jože Ftičar: Za nápršnjek vedríne I, II. Murska Sobota: Založba Stopinje. 2004, 2006. Časopis za zgodovino in narodopisje 78/2-3. 224-227.

Jože FTIČAR, 1966: Slovenci na levi in desni strani Mure in njihovi kulturni stiki (do 1919). Panonski zbornik. Murska Sobota. 117-130.

--, 2006: Dramilo Porabskih Slovencev ali njihov labodji spev? Ob prvem slovarju in prvem romanu v porabski slovenščini. Traditiones 35/1. 159-166.

Marc L. GREENBERG, 1988: Slovar beltinskega prekmurskega govora. Slavistična revija 36. 452-456.

--, 1993: Glasoslovni opis treh prekmurskih govorov in komentar k zgodovinskemu glasoslovju in oblikoglasju prekmurskega narečja. Slavistična revija 41/4. 465-487.

- -, 2007: Francek Mukič. Porabsko-knjižnoslovensko-madžarski slovar. Slovene Studies 29/1-2, 103-106 (dostopno 29. 4. 2010 na: http://www.slovenestudies.com/ misc/book_reviews/MukicGreenberg.pdf).

Mojca HORVAT, 2008: Narečna podoba Prekmurja (po gradivu za Slovenski lingvistični atlas). Življenje in delo Jožefa Borovnjaka. Maribor. Zora 55. 235-256.

Marko JESENŠEK, 2005: Spremembe slovenskega jezika skozi čas in prostor. Maribor. Zora 33.

Vida JESENŠEK, 2009: Ponazarjalni primer in slovaropisna obravnava frazeologije. Annales 19/2. 1-10.

Franci JUST, 2006: Panonski književni portreti 1. Prekmurje in Porabje A-I. Murska Sobota. 11-19.

Karmen KENDA JEŽ, 2001: Nadnarečne prvine v narečnem slovarju? Słowiańszczyzna w kontekście przemian Europy końca XX wieku: język - tradycja-kultura. Katowice.

Mihaela KOLETNIK, 2008: Panonsko lončarsko in kmetijsko izrazje ter druge dialektološke razprave. Maribor: Mednarodna založba Oddelka za slovanske jezike in književnosti, Filozofska fakulteta. (Mednarodna knjižna zbirka Zora, 60).

Francek MUKIČ, 2005: Porabsko-knjižnoslovensko-madžarski slovar. Szombathely: Zveza Slovencev na Madžarskem.

Franc NOVAK, 1996: Slovar beltinskega prekmurskega govora. Drugo, popravljeno in dopolnjeno izdajo priredil in uredil Vilko Novak. Murska Sobota.

Vilko NOVAK, 2006: Slovar stare knjižne prekmurščine. Ljubljana.

Marko SNOJ, 2009: Slovenski etimološki slovar. Druga, pregledana in dopolnjena izdaja. Prvi ponatis. Ljubljana.

Marija STANONIK, 2008: Slovenska narečna književnost. Maribor: Slavistično društvo. Zora 51.

Peter WEISS, 2000: Označevanje v slovenskih narečnih slovarjih. Jezikoslovni zapiski 6. 27-44. 
- -, 2009: Novejši prekmurski narečni slovarji. Slovenski mikrokozmosi-medetnični in medkulturni odnosi. Ur. Irena Novak Popov. Ljubljana: Slavistično društvo Slovenije. 52-61.

Zinka ZORKO, 1998: Haloško narečje in druge dialektološke študije. Maribor. Zora 6.

- -, 2005: Prekmursko narečje med Muro in Rabo na vseh jezikovnih ravninah primerjalno z današnjim nadnarečnim prekmurskim knjižnim jezikom. Prekmurska narečna slovstvena ustvarjalnost. Murska Sobota. 47-68.

http://ola.zrc-sazu.si/OLA-VSE/FO_1981_000--026_UVOD.pdf (dostopno 29. 4. 2010).

\section{LEXICOGRAPHICAL MATERIAL IN FTIČAR'S NOVEL ZA NÁPRŠNJEK VEDRÍNE}

Jože Ftičar, dialectologist, translator, screenwriter and writer in the Prekmurje dialect (Just 2006: 184), published his novel Za nápršnjek vedrine in two parts (the first appeared in 2004 and the second in 2006). The novel, epistolary in form, is the first of its kind to be written in the "Dolinsko" (Dolina) variety of the Prekmurje dialect. However, it can still be considered a continuation and upgrading of old Prekmurje literary production. The period in question (i.e., from the 1930s to the end of World War II) thus represents an important example of the gradual bridging of the linguistic gap between both banks of River Mura.

The author also published a supplement to the novel, namely, the dictionary Slovar narečnih besed in besednih zvez dólinskega Prekmurja, in which he gathered almost 3,000 lexemes he assumed would be unfamiliar to the modern (non)Prekmurje reader. According to Novak's dictionary Slovar beltinskega prekmurskega govora approximately half of the words in Ftičar are new, partly due to the specific content (of the novel), which is not represented in the general dialect dictionary and partly due to new wordformational requirements of the written (standard) language. The analysis showed that Ftičar's dictionary includes both contemporary dialectal expressions and archaic standard Prekmurje vocabulary furnished with the appropriate temporal qualifiers.

Ftičar's lexicographical material undoubtedly exceeds the needs of the Prekmurje addressee, and could thus be recommended not only to the reader of the novel as the primary user, but also to anybody who wishes to understand the meaning of some specific Prekmurje expression, be it from texts written in the old standard Prekmurje variety or from more contemporary Prekmurje literary works. 


\title{
Le dialecte natal: analyse de l'opinion des intellectuels et des villageois de Lituanie
}

\author{
Genovaité KaČiušKienè \\ Université de Šiauliai, Faculté des sciences humaines, \\ P. Višinskio 38,LT-76352 Šiauliai, geno@splius.lt
}

\begin{abstract}
Članek temelji na izsledkih raziskave andragoške fakultete za humanistične študije šiauliajške univerze v Litvi (Faculty of Humanities of the University of Adult Education of Šiauliai), katere namen je bil ugotoviti: (1) kako mestno okolje in družba vplivata na pojmovanje narečja in njegovo rabo, (2) koliko šiauliajških intelektualcev srednjih let, ki so se pred nekaj leti izselili iz rojstne regije, še zmeraj govori v narečju ali celo v knjižni litovščini in (3) kakšen je njihov odnos do različnih narečij.
\end{abstract}

In the article, based on a research questionnaire conducted in the Faculty of Humanities of the University of Adult Education of Šauliai, we attempt to ascertain, 1) how the city's environment and social dependence influence the conception of dialect and its usage, 2) how many intellectuals of Šiauliai of a mature age, who moved from their native region several years ago, still speak dialect or even standard Lithuanian and 3) what their attitude is toward different dialects.

Ključne besede: litovščina, narečje, identiteta, raziskovalna vprašalnica, sociolingvistična analiza

Key words: Lithuanian, dialect, identity, research questionnaire, sociolinguistic analysis

\section{Introduction}

Le lituanien (avec le letton) est l'une des deux seules langues, qui subsiste de la famille balte du groupe des langues indo-européennes. ${ }^{1}$

${ }^{1}$ L'écriture latine a été adoptée au XVIème siècle et l'alphabet contient 32 lettres. Res-
semblances avec d'autres langues: verbes perfectifs et imperfectifs comme dans les 
Le lituanien comporte deux grands groupes dialectaux : celui de l'ouest, la Basse-Lituanie ou Samogites (Žemaitija), et celui de l'est, la Haute-Lituanie (Aukštaitija), qui a donné naissance à la langue littéraire moderne. Les différences entre ces deux groupes de dialectes sont importantes, la solution est donc d'utiliser la langue littéraire pour être bien compris (V. Ambrazas 1997: 5).

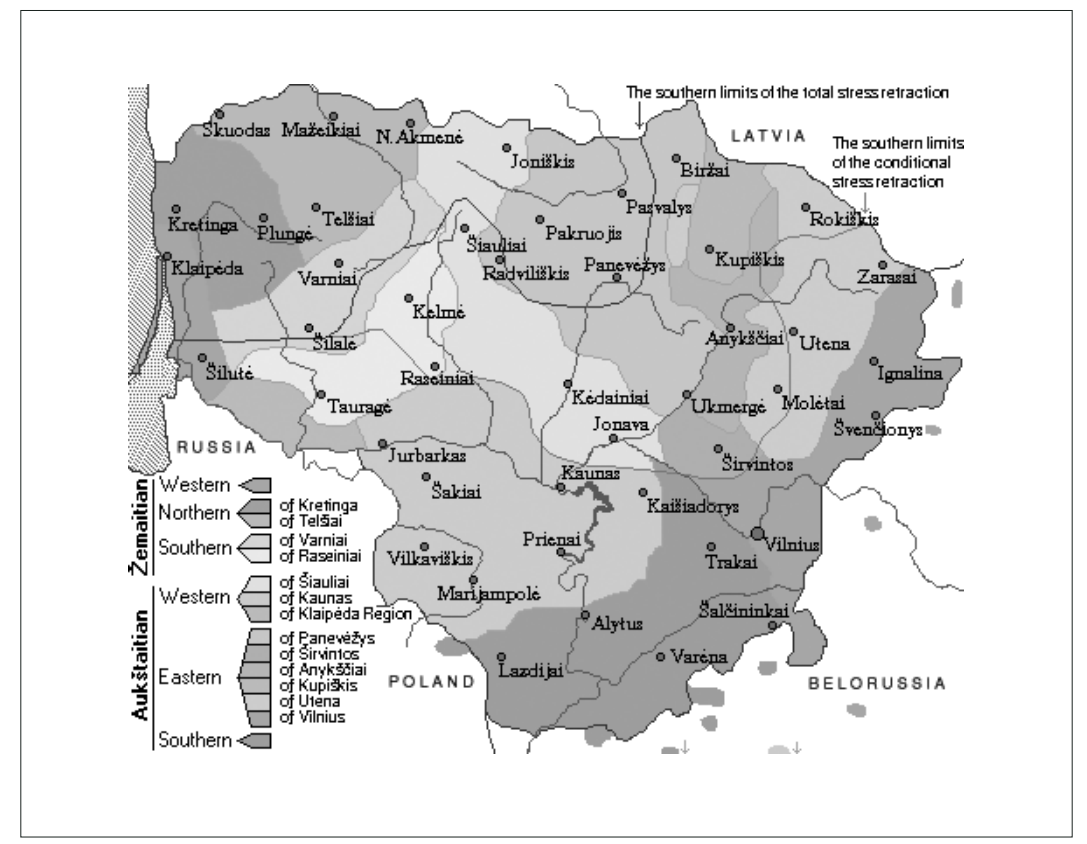

Carte 1. Les dialectes lituaniens. ${ }^{2}$ Préparée par l'Institut de la langue lituanienne (www.lrytas.lt/str_foto_galerija.asp?id=24045).

Il y a deux objectifs de cet article : 1) analyser quelle influence une ville et l'éducation exercent sur le dialecte et son emploi, 2) comment des intellectuels non linguistes considèrent les dialectes du lituanien et ses particularités.

langues slaves ou le grec; absence d'articles définis et indéfinis comme en russe ou en latin par exemple; double déclinaison des adjectifs (définis et indéfinis) comme en islandais, russe, etc. nombreux mots indo-européens ressemblant au vocabulaire slave, latin, germanique, grec; présence d'un datif absolu pour le sujet dans les phrases participiales rappelant l'ablativus absolutus en latin; système de préverbes très complexe comme dans les langues slaves ou germaniques, etc (P.U. Dini 2000: 128-179).

${ }^{2}$ La ligne N. Akmenè, Šiauliai, Raseiniai, Tauragè sépare la Basse-Lituanie de la HauteLituanie (R. Bacevičiūtè 2004: 29). 


\section{Methodologie de l'expérience}

Au cours de l'analyse on a présenté un questionnaire anonyme aux auditeurs de l'Université de Troisième Âge de Šiauliai, ${ }^{3}$ originaires de différentes localités dialectales de la Lituanie, mais habitant déjà depuis quelques dizaines d'années une ville de taille moyenne.

Pour cette raison on a proposé 10 questions à répondre:

Est-ce que vous parlez votre dialecte natal?

Qui est ce qui vous a appris à parler le dialecte?

Pourquoi est-ce que vous parlez (ne parlez pas) le dialecte?

Est-ce que vous trouvez votre dialecte natal beau (pas beau)? Pourquoi?

Est-ce que vous aimez (n'aimez pas) parler le dialecte?

Pourquoi est-ce que vous aimez (n'aimez pas) parler le dialecte?

D'après vous, quand convient-il de parler le dialecte.

D'après vous, quand ne convient-il pas de parler le dialecte?

Quand est-ce que vous parlez le dialecte?

Vos enfants (si vous en avez) parlent-ils votre dialecte?

220 personnes interrogées ont rempli les questionnaires, parmi eux il y avait 120 Hauts-Lituaniens et 100 Bas-Lituaniens.

\section{Traitement des résultats}

Toutes les réponses reçues peuvent être classées en 4 groupes selon: 1) la situation linguistique dans la ville de Šiauliai en Lituanie, 2) la motivation de parler le dialecte, 3) la fonction esthétique du dialecte et 4) les localités d'utilisation du dialecte.

\subsection{Situation linguistique dans la ville de Šiauliai en Lituanie}

Après avoir fait une analyse des réponses aux enquêtes, on a découvert (diagramme 1) que 33\% des Hauts-Lituaniens et 70\% des Bas-Lituaniens consultés habitant Šiauliai depuis plusieurs années parlent encore leur dialecte. $67 \%$ de Hauts-Lituaniens ne parlent pas le dialecte, mais 33\% d'entre eux l'avaient parlé ou savaient le parler. $30 \%$ de Bas-Lituaniens ne parlent pas le dialecte.

Les enquêtes montrent que $84 \%$ des enfants des Hauts-Lituaniens ne parlent pas le dialecte et $16 \%$ parlent encore le dialecte chez eux, dans la vie quotidienne. Tandis que $40 \%$ des enfants des Bas-Lituaniens parlent encore samogitien, 30\% parlent un patois de Šiauliai, et seulement 30\% ne parlent aucun dialecte.

${ }^{3}$ C'est l'université publique pour les personnes agées qui fonctionne depuis 1999 à Šiauliai (G. Kačiuškienė 2003: 88-89). 


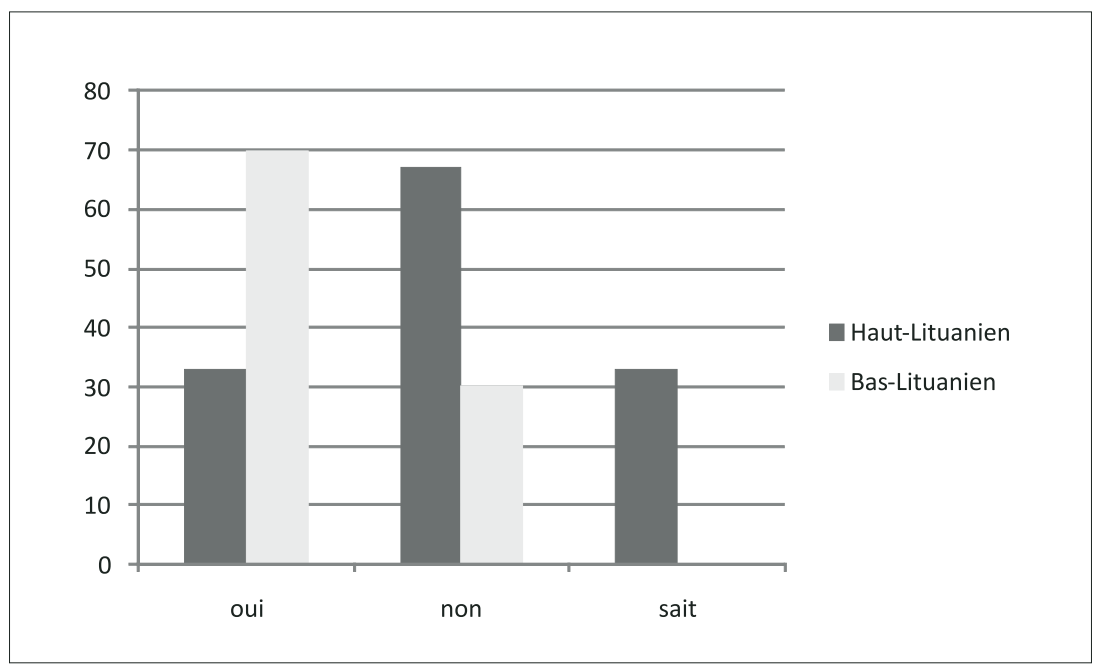

Diagramme 1. Est-ce que vous parlez (ne parlez pas) le dialecte natal?

Les enfants des Bas-Lituaniens parlent leur dialecte dans le village avec les amis, entre eux, ou quand ils sont dans leur région natale.

\subsection{Motivation de parler le dialecte}

À la question pourquoi est-ce que vous parlez le dialecte les Hauts-Lituaniens interrogés ont donné en réponse: que c'était en raison de leur souvenir d'enfance et de jeunesse; qu'il leur permettait de parler plus expressivement; qu'en parlant le dialecte on représentait son coin où on était né et où avait grandi.

Les Bas-Lituaniens parlent leur dialecte parce que: ils peuvent se souvenir de leur enfance; leur parents parlaient ce dialecte; parler le dialecte est intéressant et facile; le dialecte est plus expressif et il permet de s'exprimer à coeur ouvert. L'autre motivation est le souvenir de leurs proches - parents, personnes de la même famille, grands-parents ou l'entourage familial - qui ont appris, tout aussi bien Hauts-Lituaniens que Bas-Lituaniens, à parler le dialecte.

À la question pourquoi certains Hauts-Lituaniens n'aiment pas parler le dialecte, on peut trouver des réponses telles que: le dialecte possède beaucoup de mots étrangers; certains ne le trouvent tout simplement pas beau. Une partie des Hauts-Lituaniens consultés estiment qu'une personne cultivée doit parler la langue littéraire moderne, ils signalent que s'ils parlent leur dialecte leur famille ne les comprend pas et ricane. Les représentants de Basse-Lituanie n'aiment pas parler le dialecte à cause du langage irrégulier. 


\subsection{Fonction esthétique du dialecte}

Aux questions est-ce que vous trouvez votre dialecte natal beau (pas beau)? Pourquoi? (diagramme 2) $41 \%$ des Hauts-Lituaniens trouvent leur dialecte natal beau, 33\% ne le trouvent pas beau, 26\% des Hauts-Lituaniens trouvent leur dialecte natal moyen, étrange, assez rude.

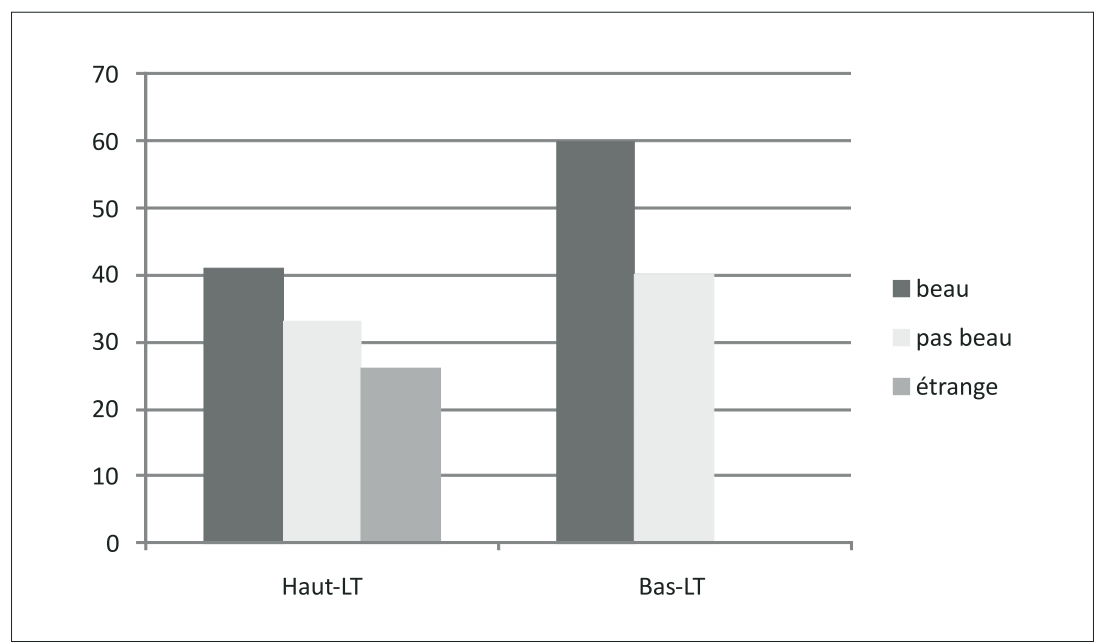

Diagramme 2. Est-ce que vous trouvez votre dialecte natal beau (pas beau)?

$60 \%$ des Bas-Lituaniens interrogés trouvent leur dialecte natal beau, intéressant ou l'aiment tout simplement. $40 \%$ des Bas-Lituaniens ne trouvent pas que leur dialecte soit beau. Malgré cela, $70 \%$ des Bas-Lituaniens et $28 \%$ des Hauts-Lituaniens aiment parler leur dialecte.

\subsection{Localités de utilisation du dialecte}

À la question quand est-ce que vous parlez le dialecte (diagramme 3) 13\% des Hauts-Lituaniens et $32 \%$ des Bas-Lituaniens ont répondu qu'ils parlaient le dialecte avec les gens de la même localité dans le village ou le bourg natal. 10\% des Hauts-Lituaniens et $28 \%$ des Bas-Lituaniens parlent leur dialecte avec les gens de leur localité partout. 10\% des Hauts-Lituaniens et des Bas-Lituaniens ne parlent leur dialecte que chez eux.

Suivant l'opinion des Hauts-Lituaniens il ne convient pas de parler le dialecte pendant les conversations et les présentations officielles, dans les institutions, au travail, dans les émissions de télévision, dans les journaux, pendant les cours, les conférences, quand tout le monde s'exprime en langue littéraire moderne. Les Bas-Lituaniens pensent qu'il ne convient pas de parler le dialecte quand on ne se trouve pas dans le village natal, quand il y a beaucoup de gens, quand 
on se trouve entre personnes qui ne parlent pas le dialecte Bas-Lituanien ou ne le comprennent pas.

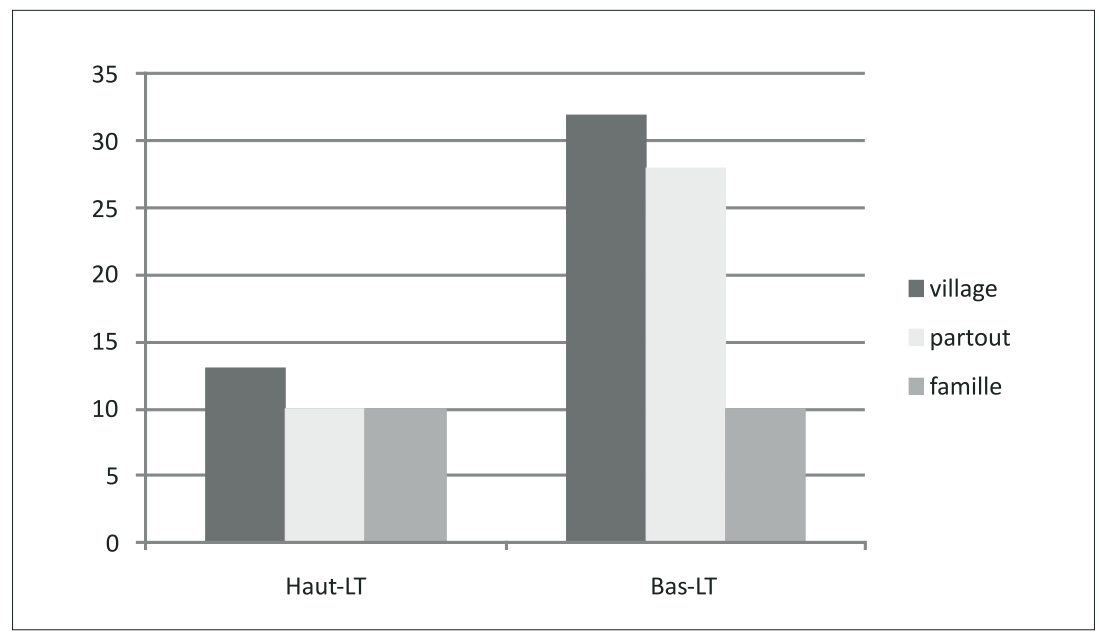

Diagramme 3. Quand est-ce que vous parlez le dialecte?

\section{Analyse comparative des expériences des Hauts-Lituaniens}

Une analyse analogue a été faite en 2003 dans le village de Sidabravas qui se trouve à côté de Šiauliai (à $30 \mathrm{~km}$ ) dans la région de Radviliškis (G. Kačiuškienè 2004: 107-109). On avait interrogé de la même manière un nombre pareil de villageois qui n'ont pas fait d'études supérieures.

Comparons par curiosité des résultats de deux analyses (diagramme 4).

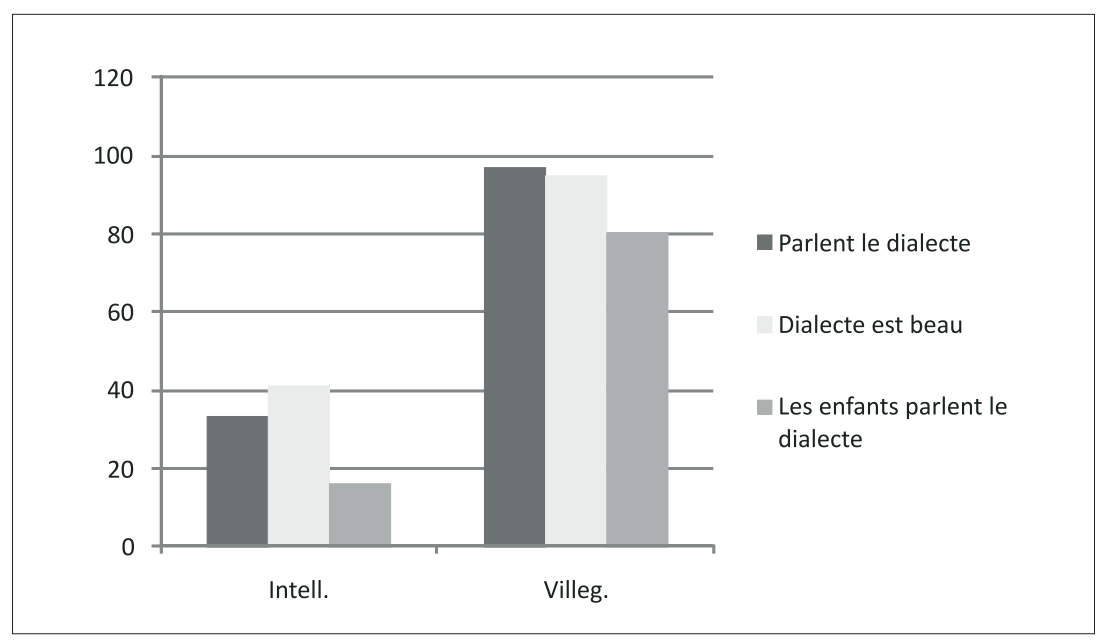

Diagramme 4. Analyse comparative des expériences des Hauts-Lituaniens 
À la question est-ce que vous parlez le dialecte natal $97 \%$ des habitants de Sidabravas ont répondu positivement. Comme les habitants de Šiauliai, ils ont appris à parler leur dialecte le plus souvent par l'intermédiaire de leurs proches: parents et grands-parents. 95\% des villageois aiment parler le dialecte. Ils parlent le dialecte avec les gens de leur localité partout (75\%) ou chez eux (25\%). D'après les villageois, il ne convient pas de parler le dialecte pendant les conversations officielles ou pendant les réunions, dans les institutions, chez le médecin, avec les personnes qui ne comprennent pas le dialecte, avec les jeunes gens, au travail, à l'école, dans les lieux publics, quand on est invité chez quelqu'un, pendant de grands attroupements. Il y avait par contre quelques personnes interrogées qui ont dit qu'il convenait de parler le dialecte partout. À la question est-ce que les enfants parlent le dialecte $80 \%$ des villageois ont répondu positivement. Comme dans les réponses des intellectuels de ville, les habitants de village expliquent que les enfants communiquent en dialecte le plus souvent à la maison, avec des amis, quand ils rentrent dans leur village, à l'école. Il y a des enfants de quelques personnes interrogées qui parlent toujours le dialecte.

Pour la plupart des villageois leur dialecte natal est beau. Les particularités dialectales les plus saillantes sont la réduction des terminaisons et la prononciation plutôt dure de la consonne $l$. Le reste des personnes interrogées ne trouvent pas leur dialecte beau: à cause de l'absence de sonorité; car il détruit la langue littéraire moderne; car le dialecte est très paysan; car on coupe les terminaisons; et car il possède beaucoup de barbarismes. D'après une personne interrogée, tous les dialectes sont laids.

\section{Conclusions}

Sur la base des deux questionnaires (celui des auditeurs intellectuels de la Faculté des sciences humaines de l'Université de Troisième Âge de Šiauliai et celui des habitants du village de Sidabravas de la région de Radviliškis sans éducation supérieure), on peut tirer ces conclusions:

1. Pour les intellectuels de Šiauliai originaires de différentes régions de la Haute-Lituanie (Aukštaitija) et de la Basse-Lituanie (Žemaitija) la conception du dialecte est la même. C'est un langage des parents et du pays natal qui est assez souvent rude et étrange et que chaque génération hérite et ensuite lègue à la suivante en tant que succession reliant cette génération à une histoire du pays et à ses habitants. C'est une langue avec laquelle on peut parler à coeur ouvert avec ses proches dans son pays natal ou chez soi.

2. Dans la perception des intellectuels de la Basse-Lituanie, le dialecte est plus important et est plus valorisé que chez les représentants de la Haute-Lituanie. C'est pourquoi on a découvert un pourcentage plus élevé de Bas-Lituaniens qui parlent le dialecte, davantage de leurs enfants ont hérité le dialecte des parents et parlent le dialecte natal. Les intellectuels hauts-lituaniens (peutêtre à cause des ressemblances de leur dialecte avec la langue littéraire 
moderne ou à cause des particularités caractérielles) abandonnent plus vite leur dialecte natal. Après avoir quitté la maison des parents, ces intellectuels ainsi que leurs enfants communiquent plutôt en langue littéraire.

3. Dans la perception des villageois hauts-lituaniens qui n'ont pas d'éducation supérieure et qui vivent dans un entourage dialectal, le dialecte occupe une place beaucoup plus considérable et joue un rôle beaucoup plus important dans la vie que ce n'était le cas dans la perception des intellectuels de la ville. On le parle presque partout et toujours, on admet et on apprécie ses particularités linguistiques.

4. Les résultats des expériences qu'on a faites permettent d'accepter la conclusion de D. Aliūkaitè (2006: 582) et de R. Urnèžiūtè (1998: 142) que, indépendamment des facteurs tels que l'âge, le lieu de résidence et la classe sociale, l'éducation exerce une grande influence sur la communication dialectale. Plus le niveau d'éducation dans une communauté linguistique est élevé, moins il y a de locuteurs dans cette communauté qui parlent le dialecte.

\section{BIBLIOGRAPHIE}

Daiva ALIŪKAITE், 2006: Tarminio kalbèjimo kultūrinis aspektas / L'aspect culturel de langage parlé. Acta Baltico-Slavica 30, 567-583.

Vytautas AMBAZAS et al., 1997: Lithuanian Grammar / Grammaire lituanienne. Vilnius: Baltos lankos.

Rima BACEVIČIŪTĖ et al., 2004: Lietuviu kalbos tarmiu chrestomatija / Chrestomathie des dialectes lituaniens. Vilnius: Lietuvių kalbos instituto leidykla.

Pietro Umberto DINI, 2000: Baltu kalbos. Lyginamoji analize / Langues baltes. Analyse comparative. Vilnius: Mokslo ir enciklopedijų leidybos institutas.

Genovaitė KAČIUŠKIENĖ, 2003: Trečiojo amžiaus universitetas Šiauliuose: klausytoju požiūris i gimtaja tarmę / Université de Troisième Âge de Šiauliai: l'attitude des auditeurs vers leur dialecte natal. Pedagogika 69, 88-93.

Genovaite KAČIUŠKIENĖ, 2004: Rytu aukštaičiu sidabraviškiu šnektos vertinimas tarmés atstovu požiüriu / Appréciation de dialecte natal par les représentants de Sidabravas de la Haute-Lituanie. Valoda-2004 14. Daugavpils: Daugavpils Universitāte.103-109.

Rita URNĖŽIŪTĖ, 1998: Kodu kaita joniškiečiu šnekamojoje kalboje / Changement de code dans le langage parlé de Joniškis. Kalbotyra 47/1, 131-142.

www.lrytas.lt/str_foto_galerija.asp?id=24045 (vu: 1511 2009). 


\section{RODNO NAREČJE: ANALIZA MNENJA INTELEKTUALCEV IN VAŠČANOV V LITVI}

Prispevek temelji na raziskavi, opravljeni na šiauliajški andragoški fakulteti za humanistične študije. Avtorica poskuša pokazati, kako sta na pojmovanje narečja in na njegovo rabo vplivala mestno okolje in družba, koliko šiauliajških intelektualcev srednjih let, ki so se pred nekaj desetletji izselili iz Litve, še vedno govori litovsko, koliko v narečju in kakšen je njihov odnos do različnih narečij.

Rezultati raziskave kažejo, da pojmovanje rodnega narečja med intelektualci, ki izhajajo iz različnih področij Aukštaitije in Žemaitije, na splošno sovpada. Gre za materni jezik oz. jezik rodne dežele, ki ga sicer pogosto opredeljujejo kot precej čudnega in robatega, a ga kljub temu ohranjajo in prenašajo iz generacije $\mathrm{v}$ generacijo kot dediščino, povezano s predniki, preteklostjo rodne dežele in njenih prebivalcev. V zavesti intelektualcev iz Žemaitije ima narečje pomembno mesto in je vrednoteno višje kot pri intelektualcih iz Aukštaitije.

Aukštaitijci, ki nimajo univerzitetne izobrazbe, pripisujejo narečju veliko večjo vlogo kot šiauliajski intelektualci. 